Article

\title{
The Effect of Shot Blasting Process on Mechanical Properties and Anti-Corrosive Behavior of Steel Reinforcement
}

\author{
Maria Basdeki *(D) and Charis Apostolopoulos
}

Citation: Basdeki, M.; Apostolopoulos, C. The Effect of Shot Blasting Process on Mechanical Properties and Anti-Corrosive Behavior of Steel Reinforcement. Metals 2022, 12, 275. https: / / doi.org/ $10.3390 /$ met12020275

Academic Editor: Alexandre Emelyanenko

Received: 28 December 2021

Accepted: 28 January 2022

Published: 2 February 2022

Publisher's Note: MDPI stays neutral with regard to jurisdictional claims in published maps and institutional affiliations.

Copyright: (C) 2022 by the authors. Licensee MDPI, Basel, Switzerland. This article is an open access article distributed under the terms and conditions of the Creative Commons Attribution (CC BY) license (https:// creativecommons.org/licenses/by/ $4.0 /)$.
Laboratory of Technology and Strength of Materials, Department of Mechanical Engineering \& Aeronautics, University of Patras, 26500 Patras, Greece; charrisa@upatras.gr

* Correspondence: mbasdeki@upnet.gr

\begin{abstract}
The need to confront the problem of corrosion resistance of steel reinforcement is an issue of major importance and a perpetual challenge to the structural integrity and reliability in reinforced concrete $(\mathrm{RC})$ structures. The current experimental study presents the results of the combined effect of shot blasting and coating on steel reinforcing bars in respect to their anticorrosive resistance and their mechanical behavior, at various times of exposure to corrosive environment. In the present manuscript, a comparison of different abrasive materials was primarily conducted, via electrochemical measurements (Tafel tests), to estimate the corrosion current $\left(i_{\text {corr }}\right)$ for each abrasive material. After the indication that corrosion resistance can be modified by shot blasting with corundum, the method of Zn85Al15 coating was chosen to further investigate the combined effect of shot blasting with coating, in terms of percentage mass loss and mechanical behavior of steel reinforcement. The results demonstrated that, upon the completion of the surface treatment process with corundum, the mechanical performance of steel bars was improved in terms of ductility. Moreover, the Zn85Al15 coating provided a satisfactory anticorrosive protection to steel bars in the entire exposure period of accelerated corrosion. The combined contribution of shot blasting and coating processes was deemed to be very encouraging and may trigger further investigation and research, for the production of a better corrosion resistance of B500c steel.
\end{abstract}

Keywords: steel reinforcement; corrosion; coating; shot blasting method; corundum shot blasting; mechanical properties

\section{Introduction}

As it is widely known, the long-term performance of reinforced concrete (RC) is assessed via two main criteria, serviceability and durability. Serviceability relates to structural integrity, the ability of the element to sustain loads throughout its life and perform its intended function. Durability refers to the ability of the material to resist changes in its microstructure and properties, particularly where such changes may adversely affect the serviceability of the element.

In the case of coastal regions or marine environments, chlorides reach the surface of concrete and enter the pore system, either by diffusion or by capillary suction of the surface water in which they are dissolved. It is apparent that there is an initiation period, until chloride ions reach the reinforcement, during which chloride ions diffuse into concrete and reach a given concentration necessary to trigger corrosion of the steel reinforcement [1]. Thus, RC structures need significant maintenance due to the harmful effect of corrosive agents on the steel reinforcement, by gradually deteriorating both the mechanical properties and ductility, which is crucial to guarantee the bearing capacity of elements and therefore the mechanical performance of RC structures.

Furthermore, corrosion impairs the mechanical response and useful service life of steel reinforcement. The experimental data of existing literature report the consequences of chloride induced corrosion, namely, the percentage mass loss and reduced cross-sectional 
area, the development of pits and stress concentration points and subsequent drop of mechanical properties of steel reinforcement [2-8]. Several studies demonstrate the cracking and spalling of concrete cover which leads to reduced bond strength between steel and concrete and reduced service life of structures [9-12].

Tempcore steel reinforcement, which is commonly used across Europe, shows excellent deformation capacity (ductility) through its ferritic core and adequate strength through its external martensitic layer. However, it has been demonstrated that this type of steel reinforcement is strongly affected by corrosive factors, starting with damage of the external martensite layer [13]. Prompted by these data, the scientific community's interest is often directed toward improvement of surface properties through shot blasting methods and coating, among other employed processes.

Shot blasting is accomplished by bombarding the surface of steel reinforcement with small sized particles (shots) made of hardened materials under high velocities. The impact of shots has been already widely reported. For instance, Voorwald et al. [14] carried out shot blasting for AISI 4340 steel through cast steel shots, and the results showed that these shots can significantly improve corrosion resistance and fatigue life of target material. Drakakaki et al. $[15,16]$ reported that the shot blasting treatment process of B500c steel had a positive impact on not only the corrosion resistance, but also the mechanical performance.

At a further level, coatings are used, to date, in many different formations and with a wide range of applicable methods, providing protection to the underlying material against degradation. The most common corrosion mitigation method for the protection of steel reinforcement involves the application of thermal protective coatings as one of the most effective way to extend the limits of its service life, by allowing the mechanical properties to be maintained. Focusing on the coatings comprised of $\mathrm{Al}, \mathrm{Zn}$, and their alloys, they are made by finely dispersed deposition of molten particles onto a substrate, providing a physical barrier against the environment when intact. More precisely, $\mathrm{Al}$ and $\mathrm{Zn}$ coatings operate on the principle of cathodic protection of steel, implemented as anodic coatings covering the steel. In addition, thermal spray is considered to be the most appropriate method due to its simplicity, low operation cost, and high efficiency. A significant amount of literature has been published over the last decades on the physical and mechanical properties of coatings [17-22]. However, there are very few reports [23,24] about the electrochemical investigation of the corrosion performance of thermally sprayed coatings exposed in a coastal area for a long term.

Hence, the need for confronting the problem of resistance of reinforcing steel bars against corrosion is an issue of great importance and a perpetual challenge to the structural integrity and reliability of reinforced concrete structures. In the present manuscript, an effort has been made to increase the corrosion resistance of the high strength and ductility dual-phase steel B500c class, with the combined use of shot blasting and coating processes, without any interference in the chemical composition or in the production mode. The main goal of the present study is to describe the influence of various levels of corrosion on different reinforcing steel bars and to evaluate the degradation of their mechanical performance, focusing on their type of shot blasting treatment. A secondary aim is to study the influence of coating material on cathodic protection of steel bars, in terms of corrosion performance, examining the case of Zn85Al15 coating towards the already existing knowledge of $\mathrm{Al}$ coating.

\section{Experimental Procedure}

The main goal of the present study is to describe the influence of various levels of corrosion on bare, shot blasted, and coated reinforcing steel bars and to evaluate the degradation of their mechanical performance, focusing on the abrasive material. The experiments were conducted on ribbed steel reinforcing bars of B500c class, the chemical composition of which is summarized in Table 1, with nominal diameter equal to $8 \mathrm{~mm}$. A total of 50 steel specimens were cut for the needs of the present study, each with a total length of $350 \mathrm{~mm}$. 
The rebars were divided into two main groups, bare and coated specimens, so as to study and compare their corrosion resistance and their mechanical performance.

Table 1. Chemical composition of B500c steel.

\begin{tabular}{cccccc}
\hline $\mathbf{C}(\%)$ & $\mathbf{S ~ ( \% )}$ & $\mathbf{P ~ ( \% )}$ & $\mathbf{C u}(\%)$ & $\mathbf{N}(\%)$ & $\mathbf{C}_{\text {eq }}(\mathbf{\%})$ \\
\hline 0.24 & 0.055 & 0.055 & 0.85 & 0.013 & 0.52 \\
\hline
\end{tabular}

The coated specimens were first submitted to shot blasting process with fused brown alumina (corundum) and then, a protective layer of Zn85Al15 with thickness 80-120 $\mu \mathrm{m}$ was formed via thermal spray with wire feed method. Hence, in the present manuscript, that group of specimens is referred as CSB (Coated and Shot Blasted). As has been indicated in previous scientific studies $[15,16,22]$, the shot blasting process may have impact on the mechanical behavior of materials, while the coating material can enhance their anticorrosive behavior.

Moreover, both main groups of bare and coated specimens were further divided into five subgroups, in order to test the specimens in different corrosion exposure times, namely 0 (non-corroded conditions), 30, 60, 90, and 120 days in salt spray chamber, respectively.

Prior to the accelerated corrosion tests, the initial mass of each specimen was recorded. Thereafter, the corrosion level of each steel bar was estimated in terms of mass loss by the following expression:

$$
\text { Percentage Mass Loss }=\frac{M_{\text {ref }}-M_{\text {cor }}}{M_{\text {ref }}} \cdot 100(\%)
$$

where $M_{\text {ref }}$ stands for the mass of non-corroded (reference) specimen and $M_{\text {cor }}$ stands for the mass of the corroded specimen.

Upon the completion of corrosion tests, mechanical tensile tests were conducted to all specimens to evaluate their mechanical performance in each case.

\subsection{Shot Blasting Procedure}

Shot blasting is a well-known and extensively used mechanical cleaning process to remove oxides and other debris from rusted surfaces of another material, as well as to improve their finish. During the process, the particles (shots) which incident on the material surface not only act abrasively, but induce compressive deformations. The grade of the desired cleanliness and surface compressive stress are the principal of the protocol related to shot blasting process. The standard grades of cleanliness for abrasive shot blasting, in accordance with NACE (National Association of Corrosion Engineer; Steel Structures Painting Council) and ISO 8501-1 (2007) are presented in Table 2.

Table 2. Visual standards for grades of cleanliness [25].

\begin{tabular}{ccc}
\hline Description & International ISO 8501 & American SSPC-SP \\
\hline White metal & Sa3 & SSPC SP5 \\
Nearly white metal & Sa2.5 & SSPC SP10 \\
Commercial blast & Sa2 & SSPC SP6 \\
Brush-off blast & Sa1 & SSPC SP7 \\
\hline
\end{tabular}

Crucial parameters for the selection of the shot blasting process are the type and geometry of the abrasive material, the flow rate, the impact angle, and the shot velocity. Typically, the geometry and hardness of the abrasive material dictate the performance of the shot blasting process. In detail, the angular particles are suitable for removing the surface impurities from the corroded steel surfaces, whereas the spherical particles smooth the rough external surface of the steel reinforcing bars. In the present manuscript, considering the encouraging results of previous studies of the authors $[15,16,22]$, the additional use of 
fused brown alumina was proposed, since its angular geometry increases the expectations for better abrasion and subsequently better mechanical performance of the reinforcing bars.

This manuscript is an extension of an ongoing experimental research, in which the influence of shot blasting process on both anticorrosive resistance and mechanical behavior of steel bars is under investigation. In this study, shot blasting treatment with brown fused alumina (corundum) was used for both cleaning and creating permanent compressive stresses on the surface of B500c reinforcement steel.

As detailed below, the characteristics of the materials, used in the entire research are:

1. Brown fused alumina (corundum) is manufactured from artificial corundum by fusion operations. The particles are very tough and sharp, having high cutting speed and efficient cleaning properties. The aluminum oxide particles produce an etch finish: the fine particles produce a dull matt finish and the rough particles produce a rough etch. This material is used both for dry blasting and also for wet blasting;

2. Olivine is an ultrabasic mineral with no free silica content. It is a grey/green odorless solid, insoluble in water. Olivine is a group name covering a family of solid solutions of iron and magnesium silicates of indefinite composition. It is a natural occurring mineral, consisting mainly of a solid solution of Forsterite (magnesium rich member) \& Fayalite (iron rich member). The mineral is mined by an open cut method, crushed, milled, screened, cleaned via a complex suction system, and stored in various product silos depending on its sizes;

3. Sinter ball is a hard and unyielding abrasive, available in spherical shapes. The steel shots are manufactured from alloyed scrap steel of superior hardness (martensite \& troostite steels), enriched with chromium alloy to achieve a very particular microstructure that does not crumble on impact and repeated shocks. The addition of chromium increases the cohesion of the material and extend the product's life;

4. Glass beads, which are a non-metallic abrasive made of soda glass, are used for shot blast cleaning, descaling, and deburring. They are also suitable for inspection blasting (fraction and fracture detection). Another application is in micro-blasting. When using glass beads, there is no abrading or scouring action, no deformation of material, and no contamination or embedment of particles. Glass beads are suitable for dry compressed air blasting, as well as for wet blast cleaning.

The materials used for the experimental program are depicted in Figure 1 and their properties are summarized in Figure 1 and Tables 3 and 4.

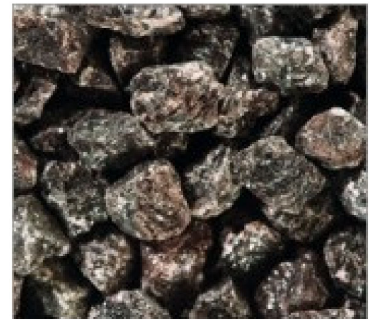

(a)

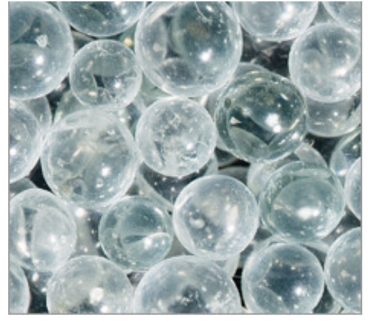

(c)

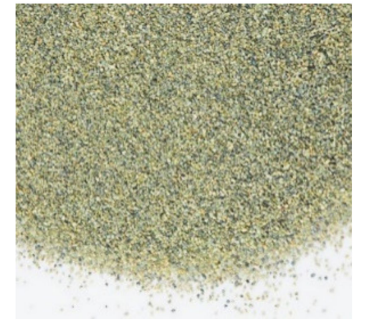

(b)

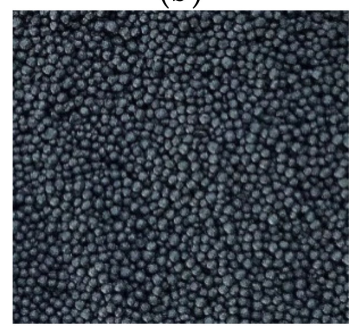

(d)

Figure 1. Abrasive materials (a) brown fused alumina (corundum), (b) olivine, (c) glass beads, and (d) sinter ball [26]. 
Table 3. Characteristics of different materials used for shot blasting method.

\begin{tabular}{|c|c|c|c|c|}
\hline Properties & Corundum & Olivine & Sinter Ball & Glass Beads \\
\hline Shape & angular & sub angular to angular & round shaped & Spherical \\
\hline Color & grey/brown & pale green & grey/black & transparent, white \\
\hline Hardness (Mohs) & 9.0 & $6.5-7$ & 9 & 6 \\
\hline Specific density $\left(\mathrm{kg} / \mathrm{dm}^{3}\right)$ & 3.9 & 3.25 & 3.77 & 2.5 \\
\hline Loose bulk density $\left(\mathrm{kg} / \mathrm{dm}^{3}\right)$ & 1.8 & - & 2.1 & 1.5 \\
\hline Grain sizes $(\mathrm{mm})$ & $0.053-2$ & $0.063-0.25$ & $\begin{array}{c}0.2-0.4 \\
0.4-08 \\
0.8-1.2\end{array}$ & $0.15-0.25$ \\
\hline
\end{tabular}

Table 4. Chemical composition (\%) of the materials under comparison.

\begin{tabular}{ccccc}
\hline $\begin{array}{c}\text { Chemical } \\
\text { Components (\%) }\end{array}$ & $\begin{array}{c}\text { Corundum } \\
\text { [Present Study] }\end{array}$ & $\begin{array}{c}\text { Olivine } \\
{[\text { [15] }}\end{array}$ & $\begin{array}{c}\text { Sinter Ball } \\
{[16]}\end{array}$ & $\begin{array}{c}\text { Glass Beads } \\
\text { [15] }\end{array}$ \\
\hline $\mathrm{Al}_{2} \mathrm{O}_{3}$ & 95.00 & $0.40-0.50$ & 78.20 & $0.8-2.0$ \\
$\mathrm{Fe}_{2} \mathrm{O}_{3}$ & 1.00 & $6.80-7.30$ & 13.00 & $0.08-0.11$ \\
$\mathrm{SiO}_{2}$ & 0.90 & $41.50-42.50$ & 4.21 & $72.0-73.0$ \\
$\mathrm{CaO}$ & 0.10 & $0.05-0.10$ & 0.22 & $7.2-9.2$ \\
$\mathrm{MgO}$ & 0.30 & $49.00-50.00$ & $-8.5-4.0$ \\
$\mathrm{TiO}_{2}$ & 2.70 & - & -8.83 & - \\
$\mathrm{K}_{2} \mathrm{O}$ & - & - & - & $0.2-0.6$ \\
$\mathrm{Cr}_{2} \mathrm{O}_{3}$ & - & $0.20-0.30$ & - & - \\
$\mathrm{MnO}_{\mathrm{NiO}}$ & - & $0.05-0.10$ & - & - \\
$\mathrm{Na}_{2} \mathrm{O}$ & - & $0.30-0.35$ & - & $13.3-14.3$ \\
$\mathrm{SO}_{3}$ & - & - & - & $0.2-0.3$ \\
\hline
\end{tabular}

The parameters for the shot blasting treatment were determined, as noted in Table 5, providing both for the quality of the material and the desired degree of oxidation removal from its surface.

Table 5. Parameters of shot blasting process compared to the existing experimental data from $[15,16]$.

\begin{tabular}{ccccc}
\hline Parameters & Corundum & Olivine & Sinter Ball & Glass Beads \\
\hline Impact angle $\left(^{\circ}\right)$ & $90^{\circ}$ & $45^{\circ}$ & $45^{\circ}$ & $45^{\circ}$ \\
Flow rate $(\mathrm{s} /$ unit $)$ & $1.0-1.2$ & $1.5-2$ & $1.5-2$ & $1.5-2$ \\
Blasting distance $(\mathrm{cm})$ & 15 & 40 & 40 & 40 \\
Degree of cleanliness & Sa2 & Sa3 & Sa2.5 & Sa2.5 \\
\hline
\end{tabular}

\subsection{Electrochemical Measurements}

In order to examine the predisposition of each material towards the corrosive factor, potentiodynamic polarization tests have been executed to estimate the corrosion potential, $\mathrm{E}_{\mathrm{corr}}$, and the corrosion current, $\mathrm{i}_{\text {corr }}$, extracted from the Tafel plots.

The experiments were executed in a $500 \mathrm{~mL}$ volume compartment consisting of threeelectrodes, namely working, counters and reference. On top of the electrochemical cell, a plastic cap was adjusted to keep the three electrodes steady. Platinum wire was used as counter electrode and silver/silver chloride $(\mathrm{Ag} / \mathrm{AgCl})$ as reference electrode. The counter electrode was placed in an open glass tube in order to lead the produced hydrogen directly out of the cell and avoid any saturation of the electrolyte with hydrogen. Helium bubbling was used in order to operate under negligible soluble oxygen conditions. The bottom and the top parts of the working electrodes were covered in wax so as to avoid additional interfaces and operate only with the electrolyte/outer steel interface. The exposed surface to the electrolyte $\left(0.5 \mathrm{M} \mathrm{H}_{2} \mathrm{SO}_{4}\right)$ was calculated assuming that the working electrode is an ideal cylinder of $8 \mathrm{~mm}$ or $12 \mathrm{~mm}$ diameter, as the case may be. The scan rate during the potentiodynamic polarization tests was kept constant at $0.3 \mathrm{mV} / \mathrm{s}$ according to ASTM G5 
standards. The temperature of the ambient, as well as the electrolyte, remained stable with a range between $18^{\circ} \mathrm{C}$ and $25^{\circ} \mathrm{C}$.

\subsection{Coating Procedure}

In a second stage, as part of the targeted extension of the present experimental research, reinforcing steel bars were submitted to thermal coating process with aluminum and zinc, and their mechanical behavior under monotonic loading was studied, in relation to specimens subjected to thermal coating process with pure aluminum [22]. Laboratory tests have shown how different types of $\mathrm{Zn} / \mathrm{Al}$ coatings protect steel against corrosion by electrochemical methods. As Buteführ has already shown [27], there are zinc alloys with an optimum percentage of $15-22 \%$ aluminum, which provide satisfactory protection against corrosion.

In that manner, for the group of specimens which was primarily submitted to shot blasting treatment with corundum, a protective layer of 80-120 $\mu \mathrm{m}$ was created via thermal spray with wire feed by Zn85Al15, namely $85 \mathrm{wt} \%$ zinc, $15 \mathrm{wt} \%$ aluminum, as reflected in Figure 2.

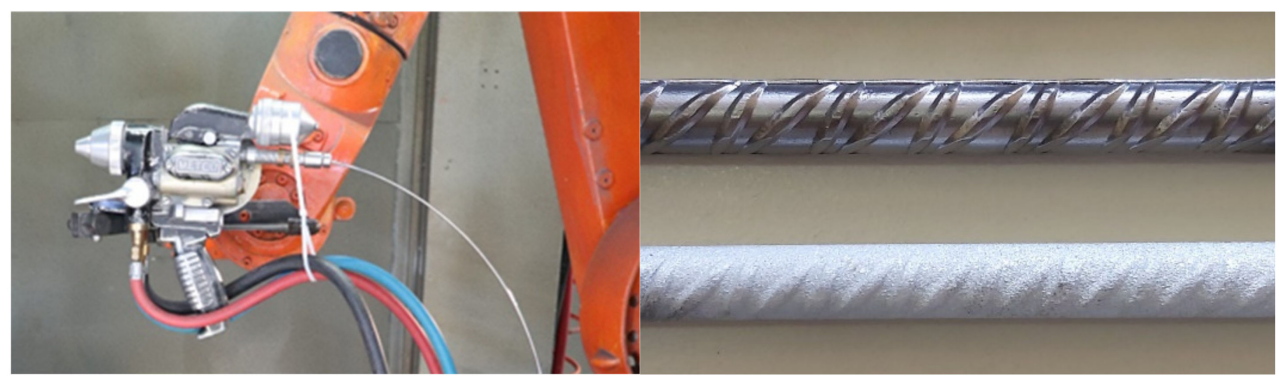

(a)

(b)

Figure 2. (a) Thermal spray coating set-up and (b) depiction of the B500c steel before and after coating.

\subsection{Accelerated Corrosion Technique}

It is common knowledge that natural corrosion is a relatively slow process, with a long period needed for the outbreak of the phenomenon, even in marine environments. Thus, accelerated methods are performed in the laboratory to reduce time and simultaneously simulate the consequences of corrosion on steel reinforcing bars.

One of the most widely used accelerated techniques, adopted in the present experimental study, is the salt spray laboratory corrosion, which was conducted in a special salt spray chamber, as shown in Figure 3, in accordance with ASTM-B117 standard [27], at different corrosion exposure times, namely 30, 60, 90, and 120 days, respectively. During the corrosion test experiment the specimens were sprayed with a $5 \%$ sodium chloride $(\mathrm{NaCl})$ solution by the weight of water and $\mathrm{pH}$ ranging between 6.5 and 7.2, switching eight wet/dry cycles a day, at $35^{\circ} \mathrm{C}$ temperature. After the exposure, the specimens were dried and in order to remove the corrosion products the specimens were cleaned according to ASTM G1-72 standard [28]. 


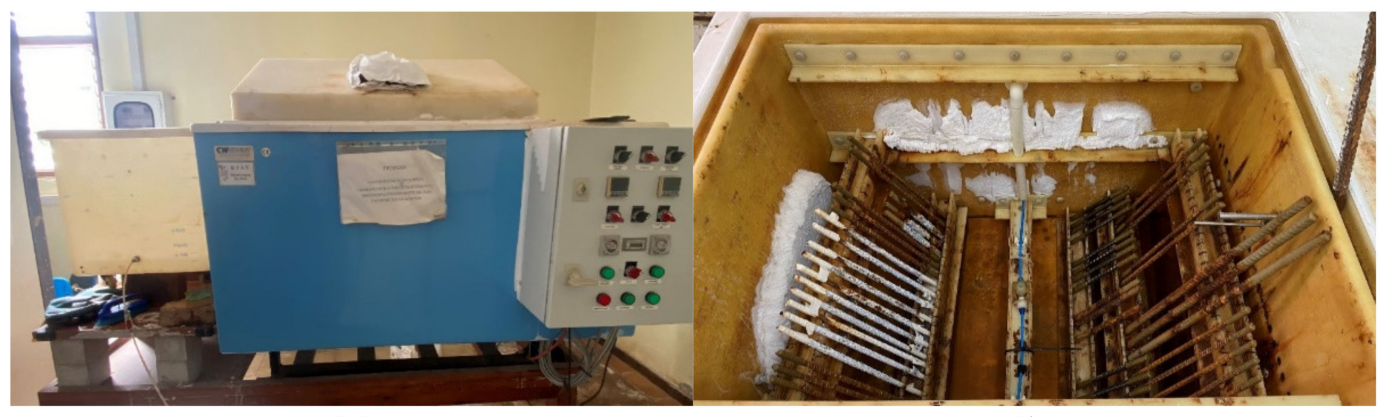

(a)

(b)

Figure 3. (a) Salt spray chamber and (b) depiction of the reinforcing bars in the salt spray chamber.

\subsection{Tensile Tests}

For all monotonic tests, a servohydraulic MTS $250 \mathrm{kN}$ machine was used. More specifically, tensile tests were conducted on non-corroded (reference) and corroded specimens of a total length of $350 \mathrm{~mm}$, for both groups of reinforcing bars for up to 120 days of corrosion exposure, according to the DIN EN ISO 6892-1 [29]. The employed displacement rate was set to $2 \mathrm{~mm} / \mathrm{min}$ and the recorded values were yield strength $\left(R_{\mathrm{p}}\right)$, ultimate strength $\left(R_{m}\right)$, plastic strain at maximum force $\left(A_{g}\right)$, and the energy absorption per volume until the corresponding value at plastic strain at maximum force $\left(\mathrm{U}_{\mathrm{d}}\right)$. Moreover, 50 mechanical tests were conducted and a total of 40 corrosion tests were conducted, as presented in Table 6.

Table 6. Test matrix for bare and Zn85Al15 coated rebars.

\begin{tabular}{cccc}
\hline \multirow{2}{*}{ Corrosion Time } & Corrosion Tests & \multicolumn{2}{c}{ Tensile Tests } \\
\cline { 3 - 4 } & & Bare & Coated \\
\hline Reference & - & 3 & 3 \\
30 days & 10 & 3 & 3 \\
60 days & 10 & 3 & 3 \\
90 days & 10 & 3 & 3 \\
120 days & 10 & 3 & 3 \\
\hline Total & 40 & 15 & 15 \\
\hline
\end{tabular}

\section{Experimental Results}

\subsection{Tafel Plots}

Figure 4 shows current-potential curves for the reference and the shot blasted with corundum specimens, in comparison with previously extracted plots of shot blasted specimens with olivine, olivine and glass beads, and sinter ball $[15,16]$. The process of cleaning was carried out according to the parameters of Table 2.

Regarding the Tafel plots, the abrasive materials retained for further analysis are corundum, olivine and olivine and glass beads. More specifically, the observed corrosion current density $\mathrm{i}_{\text {corr }}$ of the reference specimen was equal to $42.85 \mathrm{~mA} / \mathrm{cm}^{2}$, three times higher than the corrosion current observed with the shot blasted sample with olivine, and olivine and glass beads. Furthermore, the extracted corrosion current density $\mathrm{i}_{\text {corr }}$ of the shot blasted specimen with corundum was equal to $8.43 \mathrm{~mA} / \mathrm{cm}^{2}$, five times lower than that of the reference specimen. Hence, the polarization test is a first indication that corrosion resistance can be drastically modified by the shot blasting process. 


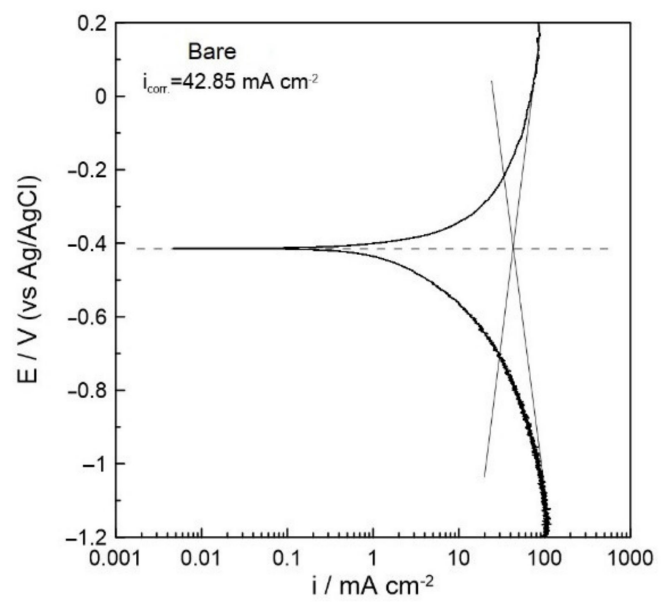

(a)

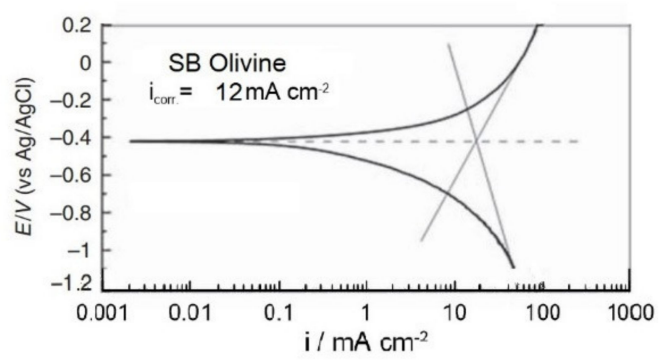

(b)

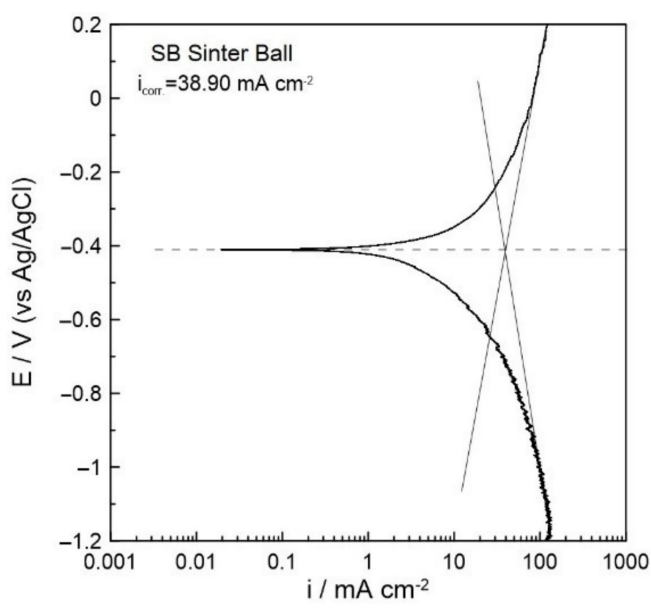

(d)

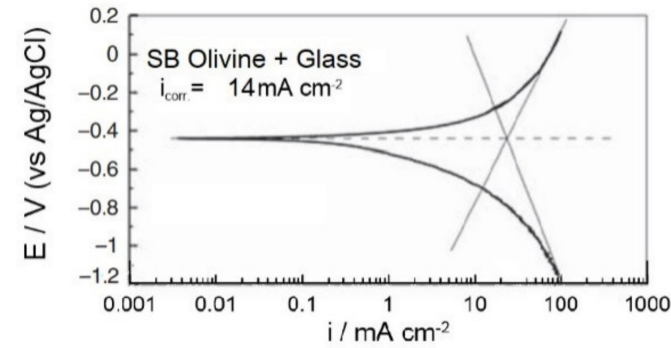

(c)

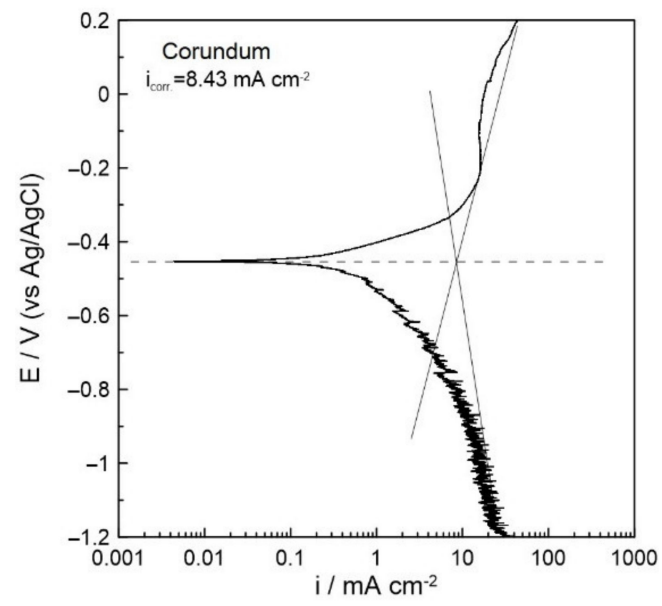

(e)

Figure 4. Tafel plots for bare (a) and shot blasted specimens, (b) with olivine, (c) with olivine and glass beads, (d) with sinter ball (data from $[15,16]$ ), and (e) with corundum.

\subsection{Mass Loss}

As mentioned in previous section, the corrosion damage of all tested reinforcing bars was estimated upon the completion of accelerated corrosion process. The recorded values are presented in the following Figure 5, for both groups of specimens, bare and CSB, compared to the previous experimental outcomes of the authors. 


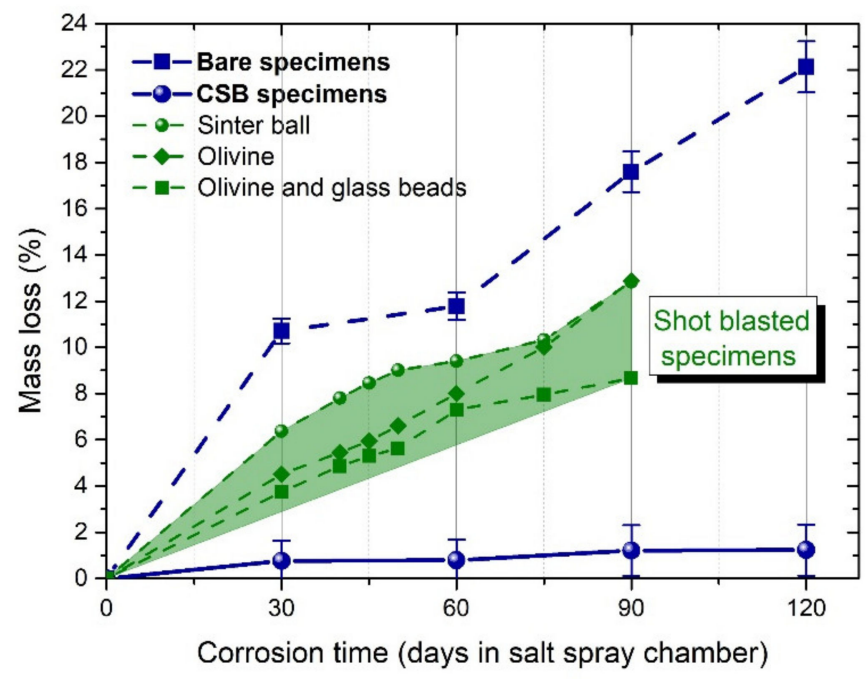

Figure 5. Mass loss of bare and CSB specimens compared to shot blasted, data from $[15,16]$.

\subsection{Results of Tensile Tests}

Tensile tests are the foremost mechanical tests to assess the mechanical performance of steel reinforcement, either in terms of strength or ductility. After the completion of the mechanical tests, values of yield, and tensile strength and ductility were extracted, as shown in Table 7, both for bare and CSB reinforcing bars.

Table 7. Results of tensile tests on bare and CSB specimens (in non-corroded and corroded conditions).

\begin{tabular}{|c|c|c|c|c|c|}
\hline Rebar & $\begin{array}{c}\text { Mass } \\
\text { Loss } \\
(\%)\end{array}$ & $\begin{array}{c}\text { Yield } \\
\text { Strength } R_{p} \\
(\mathrm{MPa})\end{array}$ & $\begin{array}{c}\text { Tensile } \\
\text { Strength } R_{\mathrm{m}} \\
\text { (MPa) }\end{array}$ & $\begin{array}{c}\text { Uniform } \\
\text { Deformation } \\
\mathrm{A}_{\mathrm{g}}(\%)\end{array}$ & $\begin{array}{l}\text { Strain Energy } \\
\text { Density } \mathrm{U}_{\mathrm{d}} \\
(\mathrm{MPa})\end{array}$ \\
\hline$b-0-1$ & - & 561 & 663 & 8.2 & 50.9 \\
\hline$b-0-2$ & - & 578 & 677 & 8.5 & 54.1 \\
\hline$b-0-3$ & - & 560 & 664 & 9.2 & 57.1 \\
\hline b-0-average & - & 566 & 668 & 8.63 & 54.0 \\
\hline b-0-dev & - & 10.12 & 7.81 & 0.51 & 3.10 \\
\hline b-30-1 & 11.14 & 496 & 588 & 5.3 & 29.0 \\
\hline b-30-2 & 8.32 & 465 & 566 & 5.4 & 28.4 \\
\hline$b-30-3$ & 11.65 & 468 & 564 & 6.2 & 32.4 \\
\hline b-30-average & 10.70 * & 476 & 573 & 5.63 & 29.9 \\
\hline b-30-dev & $1.35 *$ & 17.10 & 13.32 & 0.49 & 2.16 \\
\hline b-60-1 & 12.35 & 460 & 560 & 5.3 & 28.1 \\
\hline b- $60-2$ & 11.51 & 473 & 566 & 5.0 & 26.2 \\
\hline b- $60-3$ & 10.65 & 497 & 598 & 6.7 & 37.3 \\
\hline b-60-average & 11.77 & 477 & 575 & 5.67 & 30.5 \\
\hline b-60-dev & 0.82 & 18.77 & 20.43 & 0.91 & 5.94 \\
\hline b-90-1 & 17.49 & 508 & 601 & 5.0 & 28.5 \\
\hline b-90-2 & 17.43 & 423 & 495 & 2.4 & 11.5 \\
\hline$b-90-3$ & 18.65 & 464 & 557 & 4.7 & 24.5 \\
\hline b-90-average & 17.86 & 465 & 551 & 4.03 & 21.5 \\
\hline b-90-dev & 0.77 & 42.51 & 53.25 & 1.42 & 8.89 \\
\hline b-120-1 & 21.59 & 318 & 383 & 3.1 & 11.1 \\
\hline b-120-2 & 22.67 & 346 & 426 & 5.0 & 19.5 \\
\hline b-120-3 & 22.12 & \multicolumn{4}{|c|}{ not valid } \\
\hline b-120-average & 22.13 & 332 & 405 & 4.05 & 15.3 \\
\hline b-120-dev & 0.54 & 19.80 & 30.41 & 1.34 & 5.94 \\
\hline
\end{tabular}


Table 7. Cont.

\begin{tabular}{|c|c|c|c|c|c|}
\hline Rebar & $\begin{array}{l}\text { Mass } \\
\text { Loss } \\
(\%) \\
\end{array}$ & $\begin{array}{c}\text { Yield } \\
\text { Strength } R_{p} \\
(\mathbf{M P a})\end{array}$ & $\begin{array}{c}\text { Tensile } \\
\text { Strength } \mathbf{R}_{\mathbf{m}} \\
(\mathbf{M P a})\end{array}$ & $\begin{array}{c}\text { Uniform } \\
\text { Deformation } \\
A_{g}(\%)\end{array}$ & $\begin{array}{c}\text { Strain Energy } \\
\text { Density } U_{d} \\
(\mathrm{MPa})\end{array}$ \\
\hline$c-0-1$ & - & 539 & 655 & 13.3 & 81.9 \\
\hline$c-0-2$ & - & 541 & 646 & 10.7 & 64.9 \\
\hline$c-0-3$ & - & 536 & 656 & 11.7 & 71.1 \\
\hline c-0-average & - & 539 & 652 & 11.9 & 72.6 \\
\hline c-0-dev & - & 2.52 & 5.51 & 1.31 & 8.60 \\
\hline$c-30-1$ & 0.81 & 514 & 628 & 14.0 & 81.8 \\
\hline$c-30-2$ & 0.79 & 535 & 654 & 11.9 & 72.8 \\
\hline$c-30-3$ & 0.87 & 541 & 651 & 11.1 & 67.6 \\
\hline c-30-average & 0.76 & 530 & 644 & 12.3 & 74.1 \\
\hline c-30-dev & $0.09 *$ & 14.18 & 14.22 & 1.50 & 7.18 \\
\hline$c-60-1$ & 0.64 & 524 & 638 & 14.9 & 88.4 \\
\hline$c-60-2$ & 0.92 & 551 & 671 & 14.0 & 87.7 \\
\hline$c-60-3$ & 0.76 & \multicolumn{4}{|c|}{ not valid } \\
\hline c-60-average & 0.79 & 538 & 655 & 14.5 & 88.1 \\
\hline c-60-dev & $0.13 *$ & 19.09 & 23.33 & 0.64 & 0.49 \\
\hline c-90-1 & 1.28 & 541 & 650 & 11.0 & 66.5 \\
\hline$c-90-2$ & 1.32 & 546 & 654 & 11.7 & 71.8 \\
\hline$c-90-3$ & 1.12 & 541 & 642 & 10.5 & 63.1 \\
\hline c-90-average & 1.21 & 543 & 649 & 11.1 & 67.1 \\
\hline c-90-dev & 0.10 * & 2.89 & 6.11 & 0.60 & 4.38 \\
\hline c-120-1 & 1.31 & 539 & 651 & 11.5 & 69.7 \\
\hline c-120-2 & 0.98 & 539 & 646 & 10.5 & 63.2 \\
\hline$c-120-3$ & 1.03 & 534 & 641 & 11.4 & 68.1 \\
\hline c-120-average & 1.23 & 537 & 646 & 11.1 & 67.0 \\
\hline c-120-dev & $0.27 *$ & 2.89 & 5.00 & 0.55 & 3.39 \\
\hline
\end{tabular}

* -the value of mean mass loss has been calculated from five specimens whereas the rest values have been calculated from three specimens.

Furthermore, plastic deformation corresponding to maximum force $\mathrm{A}_{\mathrm{g}}$ for specimens of different shot blasting process, in non-corroded conditions, are presented in Figure 6, in respect to the limit of $7.5 \%$ (red line), imposed by Eurocode 2 . Blue color refers to bare and CSB specimens of the present experimental study, whereas green color refers to shot blasted specimens from previous studies.

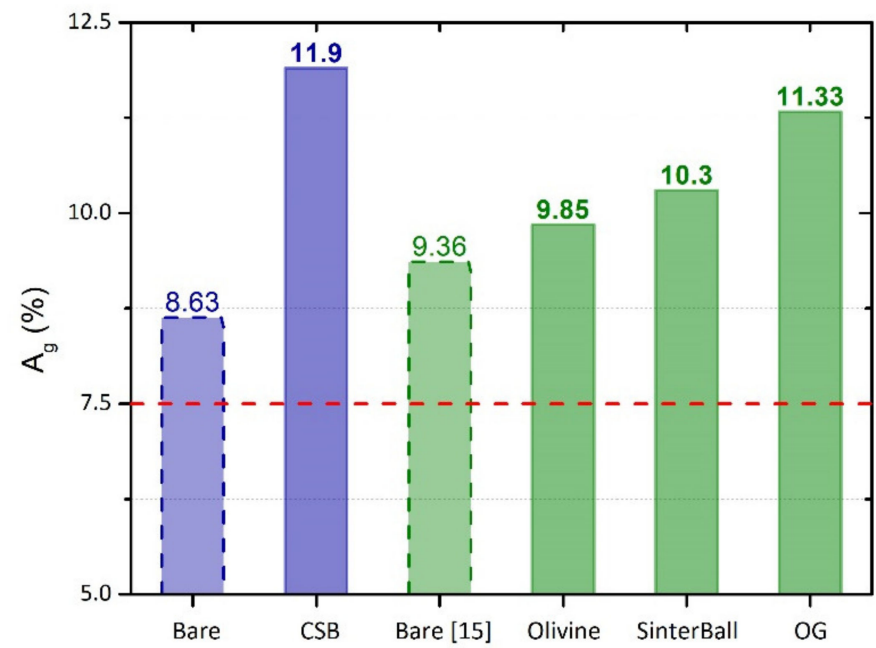

Figure 6. Plastic deformation $\mathrm{A}_{\mathrm{g}}$ to maximum force, in non-corroded conditions for all groups of specimens compared to existing experimental data $[15,16]$. 
Likewise, normalized yield stress $R_{p}$ and tensile strength $R_{m}$ for all groups of tested specimens were extracted, as presented in Figure 7. Normalized values were used in order to minimize any differences due to different batch of reinforcing bars and better compare the collected database.

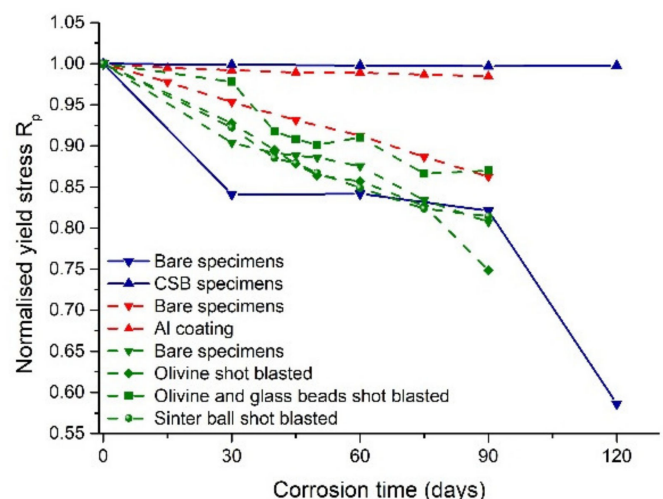

(a)

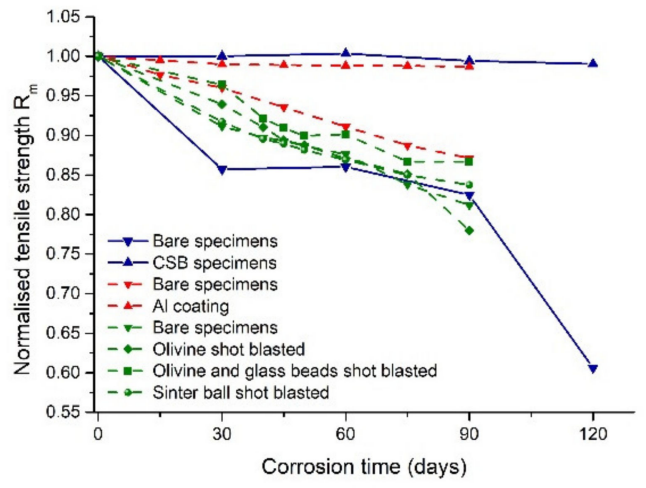

(b)

Figure 7. (a) Normalized yield stress $R_{p}$ and (b) normalized ultimate strength $R_{m}$ for bare and CSB specimens compared to experimental data $[15,16,22]$.

In this framework, the outcomes of plastic deformation to maximum force $\mathrm{A}_{\mathrm{g}}$, derived from this experimental study and combined with other comparable data in literature, which are presented relative to the corrosion time, are shown in Figure 8, allowing for investigation of their correlation. Once again, specimens of the present study are depicted with blue color, whilst green color stands for shot blasted specimens from previous studies $[15,16]$.

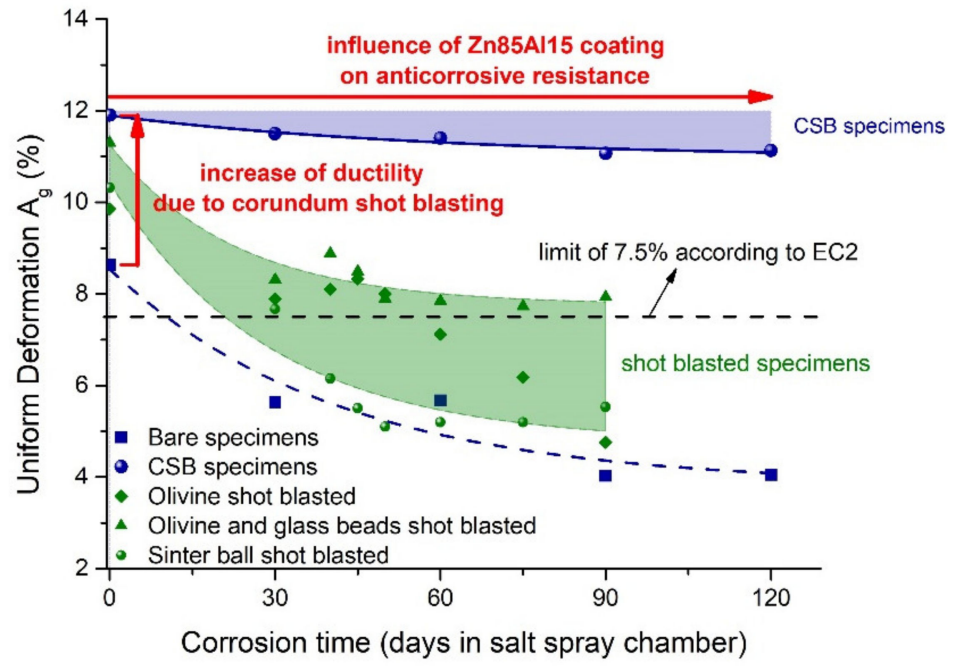

Figure 8. Plastic deformation $A_{g}$ to maximum force for all groups of specimens (data form $[15,16]$ ).

\subsection{SEM Analyses}

For the goals of the present manuscript, SEM analyses were executed both on bare and CSB specimens to examine the influence of shot blasting procedure on the external martensitic layer of steel bars. The corresponding Figures 9 and 10 for both specimens of steel reinforcement are presented below. 


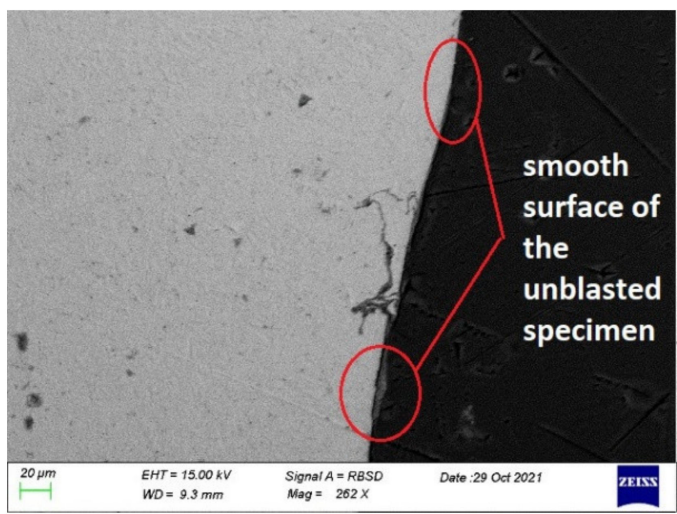

(a)

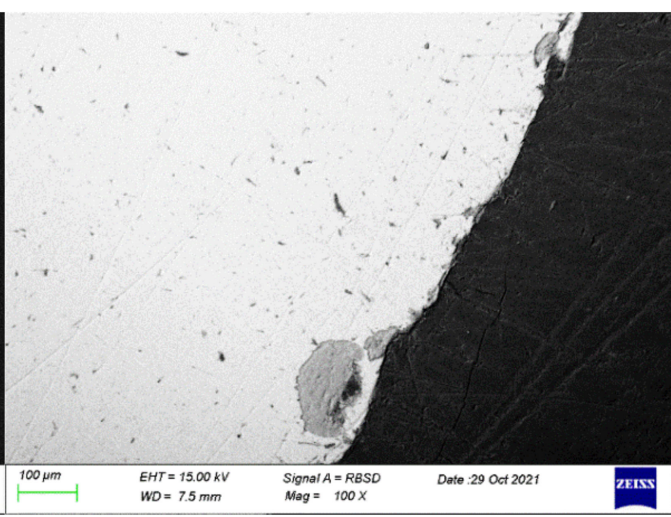

(b)

Figure 9. SEM analyses of bare specimens: (a) in non-corroded condition and (b) after a 60-day corrosion exposure and cleaning of rebars.

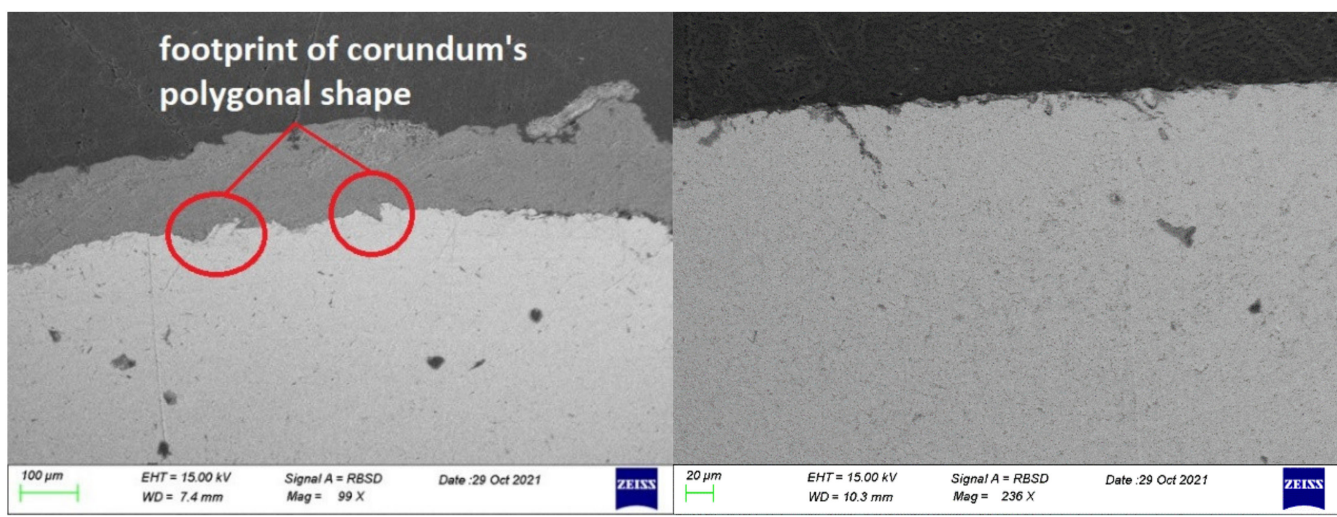

(a)

(b)

Figure 10. SEM analyses of CSB specimens: (a) in non-corroded condition and (b) after a 60-day corrosion exposure and cleaning of rebars.

\section{Discussion}

As it was expected, the exposure of steel bars in the corrosive environment resulted in gradual loss of their initial mass. From Figure 5, it is clear that bare steel specimens are more vulnerable to corrosion, since higher mass loss values were depicted for each corrosion time in contrast to the other groups of specimens, shot blasted and coated. In case of shot blasted specimens (without coating), the mass loss values indicated a modest increase compared to bare specimens, as corrosion time extends. Although the process of shot blasting is not a method of protection, the imposed compressive stresses due to the shot of the abrasive particles tend to limit the corrosion paths on the outer surface of steel bars. This is further supported when examining the SEM analyses (Figures 9 and 10), where the footprint of corundum's polygonal shape is shown on the steel surface. Thus, both the low values of corrosion current in preliminary Tafel tests and the SEM analysis bare and shot blasted steel bars in non-corroded conditions strengthened the argument that shot blasting with corundum at Sa2 degree of cleanliness were the optimal parameters in the current study. In continuance, the observations extracted from Figure 5 highlight the additional positive impact of Zn85Al15 coating on the corrosion resistance of steel bars, since the corresponding mass loss values were below of $1.5 \%$ for the entire experimental procedure. In detail, in case of 30 days of accelerated corrosion, CSB specimens recorded $0.77 \%$ mass loss compared to $10.71 \%$ of bare specimens and, in the case of 120 days corrosion, CSB specimens demonstrate mass loss at $1.23 \%$ compared to $22.13 \%$ of bare specimens.

Focusing on the shot blasted specimens (without coating), a slower degradation rate of mass loss was depicted contrary to the bare specimens, which depended on the 
type of abrasive material. The shot blasting process and its main parameters, such as the geometry and the hardness of the abrasive material, provide a limited anticorrosive resistance for a certain exposure period, since the closure of corrosion paths delays the onset of corrosion. In the present study, shot blasting with corundum combined with coating is recognized as a positive effect towards the anticorrosive behavior of steel reinforcement. The abovementioned results of corrosion tests are in a good agreement with the preliminary electrochemical tests (Tafel curves) and the extracted corrosion current values, as depicted in Figure 4.

In continuance, the results of tensile tests of bare and CSB steel bars demonstrated that the shot blasting process significantly influences their mechanical behavior. It should be emphasized that the mechanical performance of CSB bars deemed to be affected solely by the shot blasting process with corundum and not by the coating material Zn85Al15, since the average thickness of $100 \mu \mathrm{m}$ and its elastic modulus are considered to be negligible compared to the corresponding properties of steel. Observing the tensile results (Table 7) in non-corroded conditions, the recorded average value of yield strength $R_{p}$ was $566 \mathrm{MPa}$ for bare specimens and $539 \mathrm{MPa}$ for CSB specimens. Similarly, the ultimate strength $\mathrm{R}_{\mathrm{m}}$ was in line with the yield strength, as bare specimens demonstrated a value of $668 \mathrm{MPa}$ and CSB specimens a value of $652 \mathrm{MPa}$, respectively. The shot blasting process led to a slight reduction of strength properties, $4.7 \%$ in terms of yield stress and $2.5 \%$ in terms of ultimate strength. On the contrary, observing the ductility properties, shot blasting affected positively the mechanical performance. More precisely, bare specimens showed plastic deformation (at the maximum tensile force) $\mathrm{A}_{\mathrm{g}}$ equal to $8.63 \%$ and CSB specimens equal to $11.9 \%$, whereas strain energy density $\mathrm{U}_{\mathrm{d}}$ was $54.0 \mathrm{MPa}$ and $72.6 \mathrm{MPa}$ for bare and CBS specimens in non-corroded conditions, respectively. Strain energy density $U_{d}$ is defined as the area under the stress-strain $(\sigma-\varepsilon)$ curve obtained from the tensile tests, and characterizes the energy required for the steel bar fracture and express as follows:

$$
U_{d}=\frac{d U}{d V}=\int_{0}^{\Delta L} \sigma \cdot d \varepsilon
$$

where $U$ is the strain energy, $V$ the volume of steel bar, and $\Delta L$ is the elongation at fracture.

The recorded increase of ductility due to shot blasting is of major importance, since the need for a sufficient energy storage capacity of steel reinforcement is imperative especially in seismic prone areas. Since the property of energy density characterizes the damage tolerance potential of material, it is utilized to estimate the damage accumulation or the fracture either in static or in fatigue loadings. In corroded conditions, where notches and pits are developed on the steel surface, the stress intensity factor is increased due to the localized damage and can be associated with the term of strain energy so as to estimate the degradation of material [30]. Hence, the abovementioned increase of ductility properties owed only to the shot blasting encourages and strengthens the choice of corundum as a suitable abrasive material, along with the adopted cleanliness level Sa2, which was identified as the most appropriate one, as a result of several tests.

Regarding the corrosion conditions, Figure 7 shows that corrosion degrades both the strength and ductility properties of steel bars. In detail, both bare and shot blasted (without coating) specimens presented reduction of yield stress $R_{p}$ and ultimate stress $R_{m}$, respectively, as the exposure time in salt spray chamber increases. Bare specimens recorded rapid drop of yield and ultimate stress in 30 days of corrosion, at about $85 \%$ of the initial values; thereafter, a modest decline until 90 days and then a huge drop at about $60 \%$ of the initial value was depicted. On the other hand, shot blasted specimens presented gradual degradation with a time-lag in the first 60 days of accelerated corrosion, since the shot blasting process restricts the corrosion onset by limiting the corrosion paths. Slight differences between all kinds of shot blasted specimens were presented, which owed to the different abrasive material and blasting parameters. In case of CSB specimens, the influence of coating benefits the anti-corrosive resistance of steel bars, and through 
that maintains the mechanical performance in the reference non-corroded levels. In the present study, Zn85A115 was selected for the coating material in continuance of previous work of the authors, in which full aluminum coating had been studied. Comparing the normalized values of strength properties $R_{p}$ and $R_{m}$ (Figure 7) between CSB specimens (with Zn85Al15 coating) and fully Al coating, it is obvious that both coating materials provided high corrosion protection to steel bars and their mechanical properties were not affected by the corrosive environment. In this light, Zn85Al15 could be considered a better choice of coating material than aluminum due to its lower cost. A technical-financial study on the selection of the optimal coating material will be carried out in future work.

As already shown, the process of the shot blasting procedure with corundum was clearly associated with an improved performance of steel reinforcing bars in terms of ductility. CSB specimens demonstrated an increase of ductility of about $35 \%$ in respect to the bare steel bars in non-corroded (reference) conditions. Observing the values of Figure 8 , it is depicted that the combined effect of shot blasting with corundum and coating with Zn85Al15 enhanced the deformation capacity in corroded conditions, recording a rise of $\mathrm{A}_{\mathrm{g}}$ value to $174 \%$ in 120 days of accelerated corrosion. Moreover, in Figure 8 , it can be noticed that the value of plastic deformation $A_{g}$ of bare specimens, after a 30 days of corrosion, is found at the lowest limits under the set regulations $(<7.50 \%)$ for high ductile steel reinforcement.

As a matter of fact, dual phase steel reinforcement presents imperfections and defects of the material itself (microcracks and microvoids), which appear at the external martensitic layer, in parallel with high concentration of sulfides; this is a matter of general knowledge, as already reported in several studies $[13,16]$. The presence of chlorides and sulfides on steel reinforcement is considered to be crucial, as their interaction and simultaneous action leads to further development of microcracks. This interaction is further compound by the exposure to corrosive agents, resulting in subsequent formation of corrosion paths. Hence, the appropriate choice of abrasive material and parameters of shot blasting process are the key factors of the anticorrosive resistance.

\section{Conclusions}

In the present study, an extensive experimental study was conducted on reinforced concrete elements, where the corrosion damage of the steel reinforcement was correlated with the presence or absence of the coating and shot blasting processes. From this investigation, the following outcomes were obtained:

- Thermal sprayed Zn85Al15 coating showed satisfactory corrosion resistance in the environments investigated within the scope of the present work;

- Noticeable stability of the mechanical performance of the CSB specimens without any change of the outer martensitic layer and reduction of mechanical properties, in contrast to the bare specimens where noticeable mass loss and reduction of the mechanical characteristics was observed;

- The optimal choice of abrasive material and the degree of cleanliness in the shot blasting process can enhance the ductility properties of steel reinforcement;

- Shot blasting is not a corrosion protective method. However, the shot blasting process provides a time-log onset of corrosion, since compressive stresses are imposed on the external surface of steel bars, resulting in limitation of the corrosion paths in the martensitic layer;

- $\quad$ The combined action of shot blasting with corundum and coating with Zn85Al15 benefits the mechanical performance of steel reinforcing bars in long terms. Shot blasting with corundum particles increased the deformation capacity, which has been maintained due to the layer of Zn85Al15 coating.

Author Contributions: Methodology, M.B. and C.A.; investigation, M.B.; writing-original draft preparation, M.B.; writing-review and editing, C.A.; supervision, C.A. All authors have read and agreed to the published version of the manuscript. 
Funding: This research received no external funding.

Data Availability Statement: Not applicable.

Conflicts of Interest: The authors declare no conflict of interest.

\section{References}

1. Apostolopoulos, C.A.; Koulouris, K. Corrosion Effect on Bond Loss between steel and concrete. In Structural Integrity and Failure; Oyguc, R., Tahmasebinia, F., Eds.; IntechOpen: London, UK, 2020. [CrossRef]

2. Zhang, W.; Song, X.; Gu, X.; Li, S. Tensile and fatigue behavior of corroded rebars. Constr. Build. Mater. 2012, 34, 409-417. [CrossRef]

3. Caprili, S.; Moersch, J.; Salvatore, W. Mechanical performance vs. corrosion damage indicators for corroded steel reinforcing bars. Adv. Mater. Sci. Eng. 2015, 2015, 739625. [CrossRef]

4. Caprili, S.; Salvatore, W. Mechanical performance of steel reinforcing bars in uncorroded and corroded conditions. Data Brief 2018, 18, 1677-1695. [CrossRef] [PubMed]

5. Fernandez, I.; Berrocal, C.G. Mechanical Properties of 30 Year-Old Naturally Corroded Steel Reinforcing Bars. Int. J. Concr. Struct. Mater. 2019, 13, 9. [CrossRef]

6. Imperatore, S.; Rinaldi, Z.; Drago, C. Degradation relationships for the mechanical properties of corroded steel rebars. Constr. Build. Mater. 2017, 148, 219-230. [CrossRef]

7. Andisheh, K.; Scott, A.; Palermo, A.; Clucas, D. Influence of chloride corrosion on the effective mechanical properties of steel reinforcement. Struct. Infrastruct. Eng. 2019, 15, 1036-1048. [CrossRef]

8. Gu, X.; Guo, H.; Zhou, B.; Zhang, W.; Jiang, C. Corrosion non-uniformity of steel bars and reliability of corroded RC beams. Eng. Struct. 2018, 167, 188-202. [CrossRef]

9. Di Carlo, F.; Meda, A.; Rinaldi, Z. Numerical evaluation of the corrosion influence on the cyclic behaviour of RC columns. Eng. Struct. 2017, 153, 264-278. [CrossRef]

10. Koulouris, K.; Apostolopoulos, C.A. An Experimental Study on Effects of Corrosion and Stirrups Spacing on Bond Behavior of Reinforced Concrete. Metals 2020, 10, 1327. [CrossRef]

11. Hanjari, K.Z.; Coronelli, D.; Lundgren, K. Bond capacity of severely corroded bars with corroded stirrups. Mag. Concr. Res. 2011, 63, 953-968. [CrossRef]

12. Ma, Y.; Guo, Z.; Wang, L.; Zhang, J. Experimental investigation of corrosion effect on bond behavior between reinforcing bar and concrete. Constr. Build. Mater. 2017, 152, 240-249. [CrossRef]

13. Kelestemur, O.; Yıldı, S. Effect of various dual-phase heat treatments on the corrosion behavior of reinforcing steel used in the reinforced concrete structures. Constr. Build. Mater. 2009, 23, 78-84. [CrossRef]

14. Voorwald, H.J.C.; Silva, M.P.; Costa, M.Y.P.; Cioffi, M.O.H. Improvement in the fatigue strength of chromium electroplated AISI 4340 steel by shot peening. Fatigue Fract. Eng. Mater. Struct. 2009, 32, 97-104. [CrossRef]

15. Drakakaki, A.; Apostolopoulos, C.A.; Katsaounis, A.; Bjorn, H. Corrosion resistance and mechanical characteristics of dual-phase steel B500c, after shot blasting processes. Int. J. Struct. Integr. 2017, 8, 544-564. [CrossRef]

16. Drakakaki, A.; Apostolopoulos, C.A. The Mechanical Characteristics of B500c Dual Phase Steel Category, After Two Different Shot Blasting Processes. Mater. Sci. Eng. Adv. Res. Spec. 2017, 45-51. [CrossRef]

17. Kuroda, S.; Kawakita, J.; Takemoto, M. Marine Exposure Tests of Thermal Sprayed Coatings in Japan. Thermal Spray Committee Japan Association of Corrosion Control, Tokyo, Japan. In Thermal Spray 2003: Advancing the Science E Applying the Technology; Moreau, C., Marple, B., Eds.; ASM International: Materials Park, OH, USA, 2003.

18. Panossian, Z.; Mariaca, L.; Morcillo, M.; Flores, S.; Rocha, J.; Pena, J.J.; Herrera, F.; Corvo, F.; Sanchez, M.; Rincon, O.T.; et al. Steel cathodic protection afforded by zinc, aluminium and zinc/aluminium alloy coatings in the atmosphere. Surface Coat. Technol. 2005, 190, 244-248. [CrossRef]

19. Büteführ, M. Zinc-Aluminium-Coatings as Corrosion Protection for Steel. Mater. Corros. 2007, 58, 721-726. [CrossRef]

20. Gulec, A.; Cevher, O.; Turk, A.; Ustel, F.; Yilmaz, F. Accelerated Corrosion Behaviors of Zn, Al and Zn/15Al Coatings on a Steel Surface. Mater. Tehnol. 2011, 45, 477-482.

21. Bobzin, K.; Öte, M.; Knoch, M.A. Corrosion behaviour of thermally sprayed Zn, ZnMgAl and ZnAl15 coatings. In The Annual Congress of the European Federation of Corrosion; Eurocorr: Prague, Czech Republic, 2017.

22. Diamantogiannis, G.; Apostolopoulos, C.A.; Nikolakopoulos, P. Mechanical Behavior of B500c Steel with an Aluminum Layer Coating in a Marine Environment. J. Mater. Civ. Eng. 2015, 27, 04014155. [CrossRef]

23. Nuriya, H.; Suzuki, T.; Ishikawa, K.; Kitamura, Y. Corrosion resistance of thermal sprayed film of $\mathrm{Zn} \mathrm{Al}$ and $\mathrm{Zn}-\mathrm{Al}$ alloy against atmosphere corrosion. Zairyo-to-Kankyo 2002, 51, 404-409. [CrossRef]

24. Katayama, J.H.; Kuroda, S. Long-term atmospheric corrosion properties of thermally sprayed $\mathrm{Zn}, \mathrm{Al}$ and $\mathrm{Zn}-\mathrm{Al}$ coatings exposed in a coastal area. Corros. Sci. 2013, 76, 35-41. [CrossRef]

25. ISO 8501-1:2007(en); Preparation of Steel Substrates before Application of Paints and Related Products-Visual Assessment of Surface Cleanliness, Part 1: Rust Grades and Preparation Grades of Uncoated Steel Substrates and of Steel Substrates after Overall Removal of Previous Coatings. ISO: Geneva, Switzerland, 2007. 
26. Neodynamiki Ltd. Sandblasting Materials. Available online: https://www.neodynamiki.gr/\%CF\%85\%CE\%BB $\%$ CE $\%$ B9 $\%$ CE $\%$

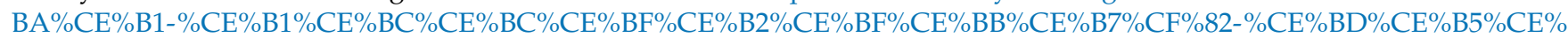
$\mathrm{BF} \% \mathrm{CE} \% \mathrm{~B} 4 \% \mathrm{CF} \% 85 \% \mathrm{CE} \% \mathrm{BD} \% \mathrm{CE} \% \mathrm{~B} 1 \% \mathrm{CE} \% \mathrm{BC} \% \mathrm{CE} \% \mathrm{~B} \%$ \%E $\% \mathrm{BA} \% \mathrm{CE} \% \mathrm{~B} 7]$ (accessed on 8 November 2021).

27. ASTM Standard B117; Standard Practice for Operating Salt Spray (Fog) Apparatus. ASTM International: West Conshohocken, PA, USA, 2003. [CrossRef]

28. ASTM Standard G1; Standard Practice for Preparing, Cleaning, and Evaluating Corrosion Test Specimens. ASTM International: West Conshohocken, PA, USA, 2011.

29. ISO 6892-1:2019(en); Metallic Materials—Tensile Testing_Part 1: Method of Test at Room Temperature. ISO: Geneva, Switzerland, 2019.

30. Apostolopoulos, C.A.; Pasialis, V.P. Use of quality indices in comparison of corroded technical steel bars B500c and S500s on their mechanical performance basis. Constr. Build. Mater. 2008, 22, 2325-2334. [CrossRef] 